Cahiers $d u$ MONDE RUSSE

\section{Cahiers du monde russe}

Russie - Empire russe - Union soviétique et États indépendants

$56 / 4 \mid 2015$

Médiateurs d'empire en Asie centrale (1820-1928)

\title{
Top Down vs. Bottom-up: Regarding the Potential of Contemporary "Revisionism"
}

\section{Oleg Khlevniuk}

Traducteur : Aaron Hale-Dorrell et Angelina Lucento

\section{Q OpenEdition}

\section{Journals}

Édition électronique

URL : http://journals.openedition.org/monderusse/8253

DOI : $10.4000 /$ monderusse. 8253

ISSN : $1777-5388$

Éditeur

Éditions de l'EHESS

Édition imprimée

Date de publication : 1 octobre 2015

Pagination : 837-857

ISBN : 978-2-7132-2507-9

ISSN : $1252-6576$

\section{Référence électronique}

Oleg Khlevniuk, "Top Down vs. Bottom-up: Regarding the Potential of Contemporary "Revisionism" », Cahiers du monde russe [En ligne], 56/4 | 2015, mis en ligne le 01 octobre 2015, Consulté le 23 septembre 2020. URL : http://journals.openedition.org/monderusse/8253 ; DOI : https://doi.org/ $10.4000 /$ monderusse.8253

Ce document a été généré automatiquement le 23 septembre 2020 


\title{
Top Down vs. Bottom-up: Regarding the Potential of Contemporary "Revisionism"
}

\author{
Oleg Khlevniuk
}

Traduction : Aaron Hale-Dorrell et Angelina Lucento

\section{RÉFÉRENCE}

James HARRIS, ed., The Anatomy of Terror, Political Violence Under Stalin, Oxford :

Oxford University Press, 2013, 352 p.

1 In 2013, Oxford University Press published a collection of articles about Stalinist repression, edited by James Harris, and based on a conference at Leeds University in $2010 .{ }^{12}$ This new collection of articles about the Stalinist Terror of the 1930s reminds us that this topic is still worth examining, despite the fact that it has been actively studied for many years. Several significant international research projects on the topic have been successfully realized. ${ }^{3}$ New archival documents about the terror are published constantly. Given these circumstances, it is important to consider the intermediate conclusions of this new work, to reflect on its directions, intellectual debates, and possible approaches to analysis that recent research brings to light.

2 The Anatomy of Terror partially achieves the objective laid out by the editor, James Harris, of "synchronizing the watches." At the same time, this book demonstrates some disturbing and continuing tendencies in research about the events of 1937 and 1938. In this article, I propose to examine these two aspects-where this collection fits within the current state of the literature, but especially some of more objectionable arguments put forward by some of the contributors. 


\section{Figures and Historical Context}

3 The historiography of the Stalinist repression of the 1930s has covered significant ground. Contemporary research based on an examination of Soviet archives has replaced the spectacular image of the "Great Terror" suggested by the late Robert Conquest. In the early 1990s, with the opening of Soviet era archives, the first task was to determine exactly how many victims of the terror there were. Archived statistics from the Soviet punitive system revealed that during Iosif Stalin's leadership, the repressive organs did not swallow a figure in the high tens of millions, as was previously thought, but "only" a few dozen million people. Among those, victims of political repression comprised only one group. Given this, everyone agreed that the information that existed in the archives needed to be examined and elucidated.

4 Stephen Wheatcroft's chapter included in the volume under consideration is devoted to such an elucidation. Wheatcroft compares the most significant sources of statistics about the repression, and concludes that, on the whole, they do not contradict each other. Melanie Ilic's article "The Great Terror in Leningrad: Evidence from the Leningradskii martirolog" reveals an important new tendency. More and more, historians not only work on calculating the number of victims of the terror; they also study their socio-demographic characteristics. Numerous regional martyrologies (knigi pamiati), based on the accounts of witnesses, as well as the historical records themselves, make this process possible. ${ }^{4}$

5 Wheatcroft and Ilic's articles remind us that the task of researching the statistics of the repression, initiated many years ago, is far from complete. Yet the process has apparently come to a halt. Having gained access to the archives in the early 1990s, historians have engaged only in the most basic activities, such as citing pre-prepared data compiled by the Records Departments of the NKVD-MVD and the Ministry of Justice of the USSR. Despite the significance of these sources, though, ministerial statistics do not account for all acts of repression. ${ }^{5}$ An outstanding task is to determine and systematize precise information about those shot, arrested, sent to labor camps, and so on, during the entire Stalin period, including the war years. Progress has been made only in a few of these areas, the most significant of which is the mass operation of 1937-1938. As additional examinations of the statistics of the state security organs have shown, from October 1936 to November 1938, 1.7 million people were arrested in the USSR, and of them 1.5 million were convicted, including the 740,000 who were sentenced to death. These figures are not definitive; however, they do exceed the official numbers by about 8.5 percent. $^{6}$

6 This evidence of the incredible force and cruelty of state terror explains the unrelenting interest in the events of 1937-1938. It is obvious that the Great Terror reflects the essence of the Stalinist system and of Stalin himself. At the same time, the phenomenon of terror in the USSR cannot be fully understood outside the broader historical context. The authors of some of the chapters included in the volume remind us of this. David L. Hoffman examines the phenomena of European and Russian state violence in the twentieth century. He devotes particular attention to such practices as "social categorization" and "social excision." There is no doubt that during the Stalin period such practices underwent a rapid and extensive transformation. Additionally, Hoffman once again raises an important methodological issue. He writes about the correlation between the broad, historical preconditions for a phenomenon and the 
concrete reasons for and forms in which a particular phenomenon becomes reality at a given moment. Hoffman notes, "I do not argue that techniques of social categorization and social excision in themselves caused Soviet state violence." In their own articles, David Priestland and J. Arch Getty continue to develop this argument regarding the division between the general context and the direct preconditions for the phenomenon.

7 Thus, there exists a general understanding that it is important to separate the broader explanatory conceptions of Stalinist terror from the concrete conditions and reasons that led to particular acts of violence during particular years. With respect to the concrete reasons and essence of the phenomenon of 1937-1938, a particular dispute has persisted in the literature, which the volume under consideration clearly attests. On the one side, there are a group of historians that I will provisionally refer to from here as "traditionalists." 0 the other side, there are historians who for decades have been developing the concepts of "weak dictatorship" and spontaneous terror. I will equally provisionally refer to this second group (in keeping with the emerging tradition) as "revisionists."

\section{The Logic of Terror}

8 The core of the "traditionalist" approach is to treat the terror of the 1930s as a general concept that was the result of a series of concrete repressive actions. These actions were carried out according to orders from the center, in which Stalin played a leading role. The consecutive waves of terror that took place during 1937-1938 were the result of the realization of several "mass operations." The duration and objectives of these "mass operations" were determined by the country's highest leadership, and above all, by Stalin. Based on their reading of new archival documents, the majority of historians who study Stalinist terror adhere to this perspective. David Shearer and Paul Hagenloh, two authors whose scholarship on state terror in Stalin's USSR is well known, write about this once again in the volume under consideration. ${ }^{8}$ The "traditional" perspective is in general supported by the authors of the other chapters in the book.

At the same time, this collection, The Anatomy of Terror, can be viewed as the latest particular manifestation of "revisionism," and we may draw several conclusions from it about the development of revisionist thinking. Gábor Rittersporn, who has long been a supporter of "revisionism," dedicates a significant portion of his chapter about the institutional clashes between the Prosecutor's Office and the NKVD to analyzing the absence of a clear and solid plan for the "mass operations" of 1937-1938. J. Arch Getty develops his earlier concept of "weak dictatorship," which operated under pressure from the powerful nomenklatura. Wendy Goldman and William Chase continue the search for a framework to undergird the concept of "initiatives from below," which they consider an important factor in the escalation of the terror. The editor of the book, James Harris, also effectively demonstrates his tendencies toward "revisionism."

Having explained the relevance of "revisionism," Harris writes, "We still do not have an encompassing explanation of the opening phase of the Great Terror and of its evolution"(8). However, this statement hardly corresponds to reality. Thanks to enormous collections of new documents and the activity of historians over the past twenty years, we have a thorough understanding of the Great Terror, of its origins, its 
mechanisms, and the results of its "mass operations." The voluminous literature contains detailed and convincing explanations for the terror of 1937-1938. ${ }^{10}$

11 Several general theses from the latest historiography allow us to comprehend the logic of the evolution of Stalinist terror, and they deserve special mention. First, under Stalin, violence and state terror ultimately transformed into the foundational methods for solving all social-economic questions and for maintaining political stability. This factor determined the enormous scale of the repressions. Second, the cycles of ruthless and relatively weak repression matched the general oscillations of Stalin's political course. The flurry of terror in the beginning of the 1930s was related to the implementation of collectivization, and then afterwards to the crisis and starvation of 1932 and 1933. The application of economic incentives for growth, and an orientation toward an alliance with Western democracies in the face of the threat of Nazism resulted in several moments of de-escalation in the terror within the USSR from 1934 to 1935, despite the murder of Sergei Kirov. Third, changes in the scale of terror were regulated by directives from the country's leadership. The "mass operations," the plans for which were formulated in Moscow, played a critical role. If the "mass operations" had not been carried out, then the level of arrests would have fallen. Fourth, the primary focus of the terror, regardless of its intensity, was directed at members of social strata who actively resisted Stalinist politics or who were considered potential threats to the regime. Their ranks included the so-called "kulaks," peasants who resisted collectivization. Persistent targets of repression included: the pre-revolutionary privileged classes; those who had served in the White Army; and members of groups who had rivaled the Bolshevik Party (Socialist Revolutionaries, Mensheviks, etc.). Over time, the most prominent "risk groups" came to include the old Bolsheviks, those who had formed various oppositions, as well as rank-and-file party members who at different times had voiced "qualms" or criticized Stalin and his course of action. For much of the 1930s, criminal offenders, especially repeat offenders who had been convicted several times, were considered apolitical but still "socially-harmful elements."

State security organs made numerous and specific lists of these "dangerous" categories of the population. ${ }^{11}$ Many people who found themselves in these files were subjected to operational surveillance. Periodically, information from the files was used as the basis for fairly limited repression. However, during the second half of 1936 and 1937, the country's political leadership became more firmly convinced of the need either for the complete physical destruction of "anti-Soviet elements" or for their isolation in camps. This idea cannot be called new if we recall, for example, the Stalinist slogan calling for the destruction of the "kulaks" "as a class," which was first advanced in 1929 and then realized throughout the early 1930s.

From the second half of 1936, the campaign for the destruction of "enemies" "as a class" descended upon former oppositionists and nomenklatura personnel. Many within the Soviet leadership were either former oppositionists or had worked with and even befriended oppositionists. It was Stalin who formulated the ideological foundations for the destruction of former oppositionists as committed opponents who had turned into "terrorists" and "agents of foreign states." Under his leadership, the necessary party resolutions were prepared in the middle of 1936. Likewise, the script for the first Moscow show trial was prepared in August 1936, as well as the key directives that would initiate purges at the Central Committee plenum of 
February-March 1937. At the same time, the party apparatus and the organs of state security actively worked through the archives and personal files of all the upper-level

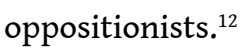

14 Having begun primarily as a complete purge of the nomenklatura, the mass repressions gradually expanded to encompass broader sections of the population. Finally, in July 1937, a directive was issued to destroy "as a class" all "anti-Soviet elements" and potential "enemies." Stalin sanctioned several "mass operations," the scale of which greatly exceeded that of analogous operations in previous years. The terror had become "Great."

In general, the documents we have today allow us to trace the specific logic of the evolution of the idea of a complete purge of the country and the definitive destruction of "enemies" "as a class." From the second half of 1936, this purge gained great strength and evolved into a universal campaign, which was directed against all possible "enemies" and "suspicious elements." The question remains as to what political mechanisms and motives drove this all-encompassing purge. It is exactly this question that is the source of dispute, including the dispute that can be characterized primarily as a dispute between "traditionalists" and "revisionists."

\section{Issuing Directives: Stalin and the Secretaries}

16 The logic and evolution of terror reached its peak in July 1937. In that month, a directive was issued regarding the conduct of a mass operation against so-called "anti-Soviet elements" based on NKVD order No.00447. Its general purpose was obvious. Within the span of a few months, the bulk of the "enemies" and "suspicious elements" should be definitively destroyed or isolated in camps. It is important to underscore that this operation was originally planned based on the existing files of the NKVD. Arrests and executions were carried out, above all, against former "kulaks." Others including "anti-Soviet elements," "White Guards," Socialist Revolutionaries, Mensheviks, and criminal offenders were also repressed.

17 The preparation and issuance of the order was carried out according to a typical Soviet bureaucratic scheme. Initially, the primary directive about the execution of the operation was passed in Moscow. In the beginning of July 1937, the regions were informed of these plans in the name of the Politburo. The order was given to guarantee that a specific number of arrests and executions would be carried out according to the information contained in NKVD materials. Afterwards these "limits" were reviewed and corrected in Moscow. On the basis of these plans, the central apparatus of the NKVD prepared order No.00447. Finally, on 31 July 1937, this order was approved by the Politburo and put into force. Originally, the operation stipulated the arrest of around 270,000 people, of whom 76,000 were subject to execution while the rest were to be sent to forced labor camps. Every region received its own plan for arrests and executions. The order stipulated also that these could be expanded with the consent of Moscow. From here on out, the directives regarding the continuation of order No. 00447 were issued by the center. At the same time, operations were initiated against people associated with so-called "counter-revolutionary national contingents"-Soviet Poles, Germans, Latvians, and many others. ${ }^{13}$ In general, all of the available documents attest to Stalin's leading role in the initiation of the mass operations. In their work, the majority of historians have proceeded according to this information. 

1937-1938 and the particular role of the "strong dictator" should have struck a blow to the "revisionist" conception of spontaneous terror, and the implication of a weak Stalin. Still, several "revisionists" have attempted to cling to their older positions, while ignoring obvious facts. ${ }^{14}$ However, these attempts have ultimately discredited "revisionism," exceeding as they do the boundaries of the rational. Two chapters in particular in the volume at hand exemplify this tendentiousness. Examination of these chapters, by J. Arch Getty, allows us to judge the current status of revisionist theory. constitution, which was founded on the restoration of voting rights to those "alien" and "enemy" elements, and above all the "kulaks," who had previously had their rights annulled. Moreover, Stalin planned to introduce free, multicandidate elections. This would have been a powerful weapon for the struggle with regional party officials, who had gained too much power. However, these officials, sensing a threat, not only forced Stalin to scrap his plans for introducing multicandidate elections, but also unleashed a campaign of mass terror in order to avoid being repressed themselves and to destroy potential opposition. It was precisely these regional secretaries who forced Stalin to confirm the decision to undertake the "mass operations," and who were also partly responsible for the issuance of order No. 00447. connected. Of course Stalin-and only Stalin-was capable issuing a directive of such significance. However, he did not issue this directive alone, but under influence and stress. In general, despite the appearance of compromise, this version nonetheless upholds the fundamental postulates of the original conceptions of "revisionism." The Stalinist political system was amorphous and weakly centralized. "The weak dictator" was not capable of independently making decisions even about such critical questions as carrying out the "mass operations."

21 In order to test Getty's account, several questions must be answered. First, was Stalin really preparing to introduce democratic elections on the basis of real nominations of alternative candidates? Today, despite a long search, there is still not one piece of evidence of such an intention. Of course, those members of the population who had earlier had their voting rights annulled once again were granted the right to participate in elections in accordance with the new 1936 Constitution. Of course, the elections became direct and secret (voting by ballot). However, these were purely decorative changes. Based as it was on terror, the political system, which was ruled by a single party and party apparatus, remained inviolable. The elections of 1937 and of the years that followed revealed this.

22 However, let us suppose that the secretaries really were afraid of multi-candidate elections. In that case, it would be important to explain how the "mass operations" would have helped them avert the threat the elections posed to their authority. This point is not explained in Getty's theory.

23 Finally, we must pose the most important question. Does any evidence exist to show that regional secretaries possessed the power to dictate their terms to Stalin? Neither Getty nor anyone else has produced such evidence. Through general phrases, without reference to facts, Getty strives to give in his works the impression that there was a dialogue of equals between Stalin and the regional secretaries-perhaps even a struggle for power! He writes about "the struggle between Stalin and an obkom secretary" (66), 
"fight between the territorial committee chiefs and the centre" (77). "The centreperiphery struggle for power [sic!] between Stalin and the regional party leaders was a real contest for power" (83).

In order to lend persuasiveness to these general "strong" theses, the volume includes a second chapter by Getty about the Yaroslavl secretary Anton Vainov. Relying on the stenographic records of the plenary sessions of the Yaroslavl oblast party committee, Getty demonstrates that Vainov was the patron of a well-formed regional network. Alone, this observation does not raise any questions. As it has long been well known, the Soviet political system was to a significant extent dependent upon the development of informal patron-client relationships. Regional secretaries, like the leaders in Moscow, surrounded themselves with "their own people." However, how does the existence of strong patron-client relations in the regions prove the thesis about the existence of a secretary with so much political power that he was capable of influencing Stalin? Getty does not answer that question.

As it happens, the example of Vainov provides equal evidence of the absolute weakness of the secretaries during the period in which the directive to carry out the "mass operations" was implemented. Suffice it to say that Vainov, after receiving comparatively mild criticism from Stalin in March 1937, had by May 1937 already been relieved of practically all his responsibilities ${ }^{15}$. In June, he was arrested and soon thereafter shot. This was a very typical fate. By July 1937, when the directive to carry out the mass repressive operations was implemented, of the fifty-eight first secretaries of the Central Committee of the Communist Party in the union republics, the krai committees, and the oblast committees, twenty-four secretaries were stripped of their responsibilities (and, as a rule, arrested and then shot): in July - eleven more, and by the end of the year - almost all of them. ${ }^{16}$ The arrests of the secretaries set off a chain reaction of purges among those who surrounded them. Functionaries in the party and the state apparatus, who, as the text tries to impress upon us, were supposedly the organizers of the terror, were actually its first victims. Demoralized by fear, they tried in every way to curry favor with their bosses and to save their own lives by demonstrating absolute obedience and devotion.

However, let us make one additional hypothetical supposition. Let us suppose that those secretaries who Stalin did not succeed in destroying before July 1937 really did possess enough strength to dictate order No. 00447 to Stalin. Do we have enough facts to support such a supposition? The one fact that Getty produces in defense of his thesis is that the Politburo's decision about "mass operation" in Western Siberia was approved on 28 June 1937. This decision sanctioned the execution of the leaders of "rebellious organizations," who had supposedly emerged from among the deported kulaks. A troika was formed for an expedited investigation of the case. ${ }^{17}$

Undoubtedly, the Politburo's decision had an important effect on the escalation of the terror. However, the question remains, was that decision dictated to Stalin by Robert Eikhe, the party leader in Western Siberia? Getty tries to prove that it was. However, the facts suggest the opposite. As Vladimir Khaustov and Lennart Samuelson demonstrate in their book, the escalation of the terror in Western Siberia, one of the most important centers for exiled "kulaks," was related to the work of the NKVD and the activities of its commissar, Nikolai Ezhov. It was in fact Ezhov who instructed the head of the directorate of the NKVD for Western Siberia, Sergei Mironov, to deal with the issue of the large-scale network of underground resisters. On 2 June 1937, Ezhov's 
deputy instructed Mironov to initiate this process, phrasing it thus: "The People's Commissar [Ezhov] attaches great importance to this matter." In accordance with these instructions, Mironov delivered fabricated materials to Ezhov. Ezhov sent them to Stalin. ${ }^{18}$

In general, as Michael Ellman has noted, "It would be a mistake to consider Mironov's report [...] as a purely regional initiative." ${ }^{19}$ Eikhe's level of participation in this act is completely unknown. Undoubtedly, he listened to Mironov's presentations and supported his activities. At the final stage of Eikhe's participation in these formal procedures, as a regional leader, he turned to Moscow with a request to conduct the operation..$^{20}$ In fact, the expansion and coordination of the operation in Western Siberia serves as an example of the model from 1937-1938. The operations were prepared by the organs of the NKVD under Ezhov's leadership, and he was in constant contact with Stalin. The secretaries supported these actions and the requests of the NKVD, which they transmitted to Moscow.

Having inflated the idea of a "secretaries' plot," the "revisionists" ignore the central role of the NKVD. Characteristically, there is one chapter in the volume at hand devoted to the state security organs. Iain Lauchlan analyzed the sources about the formation of a special caste of chekisty [officers in the security police] in the beginning of the 1920s. However, it does not help us understand what happened in the NKVD in the 1930s, especially during the period in which the Great Terror was carried out.

The theory of the "secretaries' plot" has existed for many years, but, in all that time, those who subscribe to it have been unable to produce one substantive piece of evidence to support their claims. Conversely, an enormous number of facts and documents suggest that Stalin, having issued the directive to implement the mass operations, operated as an independent force. All the other Soviet functionaries, including the leadership of the NKVD and the regional secretaries, tried actively to serve the leader's positions and the mood of the leader, which were secret to no one. ${ }^{21}$

\section{J. Arch Getty and lurii Zhukov}

31 The obvious weakness of the theory of a "conspiracy of secretaries" limits the number of its adherents to such a degree that Getty, in his contribution, names only two: himself and the Russian historian Iurii Zhukov. As a doctor of historical sciences and a fellow at the Institute of Russian History of the Russian Academy of Sciences, Zhukov is known for his plainly pro-Stalin positions. One of his books is titled The Handbook of a Stalinist. ${ }^{22}$ Zhukov makes statements hardly consistent with a scholarly perspective. In one interview, he explained the cessation of the terror thus: "In the NKVD, majority was half-literate Jews in the upper and middle ranks. It was like that in the camps, too. Almost all of them were removed. Their replacements had either a higher education or a partial one-having finished three or four years-and were primarily Russians. At that point the number of arrests began to fall sharply." ${ }^{23}$ In addition to being blatantly chauvinistic, such declarations simply do not reflect reality. Yet it is just this sort of mangling of the facts that forms the basis for numerous interviews and speeches by Zhukov in the mass media.

At the beginning of the 2000s, Zhukov became one of the advocates for re-Stalinization in Russia. Apologists for Stalin, having recovered from the shock of revelations of the "archival revolution," went on the offensive. They sought out those ideologues willing 
to say that Stalin's regime did not commit crimes, and instead was an effective model of development suited to contemporary Russia. Zhukov filled the niche that had opened for such an ideologue. As a foundation for his theory, he used Getty's contention about the elections and the secretaries. True, Zhukov rarely cited Getty's publications. He carefully concealed that he adhered to the outdated views of an American scholar. Obviously, such an "unpatriotic" appropriation might compromise Zhukov in the eyes of his "patriotic" supporters.

In numerous interviews and in his most well known book, Zhukov wrote about the democratic "other" Stalin, who strove to provide the country the best constitution and defend the people from the tyranny of the bureaucrats. ${ }^{24}$ It was these bureaucrats, Zhukov wrote, who were in fact the true culprits in the terror. In general, Zhukov "realized" Getty's contention, augmenting it with the several new attributions similar in spirit to conspiracy theories. Cleared of accusations that he organized the terror, Stalin is presented in Zhukov's works as an honorable leader struggling in the interest of the people against the ill-intentioned "oligarchs." This tale matched popular sentiment among Russian citizens seeking a "firm hand" capable of punishing the embezzlers and thieving bureaucrats of the post-Soviet period to such a degree that Zhukov's works were acclaimed as if they had revealed a higher truth.

From a scholarly point of view, however, Zhukov's works do not stand up to even the most basic scrutiny. In their reviews, professional historians noted that Zhukov violated basic norms of scholarly research: He invented facts and events. He distorted the content of real documents. At the very least, in one extremely important instance, Zhukov cited a nonexistent document. ${ }^{25}$ Criticisms of Zhukov were so convincing that he never bothered to defend himself against professional historians, but instead continued to churn out his fantastical stories for unsophisticated and politicized mass readers. No less tellingly, Getty has not heeded Russian historians' critical articles about the creations of Zhukov either, even though the articles speak directly to the links between the theories of Getty and Zhukov.

Slowly but surely, these efforts by historians in Russia have borne some fruit. The scholarly reputation of Zhukov and his theories have received sufficient censure, yet unexpected support for Zhukov has now been provided by Getty. In a review of Hagenloh's excellent book that is, in my view, undeservedly critical, Getty wrote, "Hagenloh seems unfamiliar with the books of Moscow historian Iurii Zhukov on the domestic reasons for the decision to launch the mass operations." ${ }^{26}$ The advice to utilize the arguments of a politicized publicist found guilty of "inaccuracies" appeared very strange and seemed like an accident.

However, this citation was unfortunately not an accident. Getty has actually taken Zhukov into his circle of like-minded thinkers, citing him approvingly in his recent book. ${ }^{27}$ Getty also cites Zhukov in a chapter published in the volume in question. Even more telling is Getty's citation, on page 225, of a book by Aleksandr Eliseev, a political activist and publicist of a nationalist bent and the author of pro-Stalin pamphlets in which he declares mass terror the country's salvation. For some reason, Getty refers to him as a historian.

One has to wonder what Getty's real attitude is towards the works of Zhukov and Eliseev. In this regard it is perhaps telling that he never makes use of the "facts" offered in their publications, but cites only their general reasoning and phraseology, which in some way support his theory. Whatever one's view of this particular issue, 
perhaps the more general question is whether this sort of give-and-take with unscrupulous and politically motivated journalism is appropriate for a true work of scholarship. ${ }^{28}$

\section{Motives for Stalin's Directives} authorizing the "mass operations" in 1937 provokes debate. The "traditionalists" offer a wide spectrum of possible reasons. They write of the adherence of the country's leadership to social engineering, of the danger of incidents during the elections, and of the destruction of Stalin's imagined "fifth column" amid the rising threat of war. To varying degrees, the authors of the Oxford volume underscore the importance of the moods and psychological state of Stalin. Matthew Lenoe calls attention to the fear provoked in Stalin by the Kirov murder. E.A. Rees "goes so far as to ascribe Stalin's behavior to his psychopathic personality." ${ }^{29}$ Each of these explanations has its strong points and weak points, and they should obviously be analyzed as a whole. For example, the question of setting the internal and external causes of the "mass operations" in opposition to one another is clearly of a scholastic nature. In reality, the issue is that Stalin perceived internal threats-the presence of many "enemies"-as more dangerous in 1937 because of the growing international crisis. ${ }^{30}$

event, the principal position of the "traditionalists" is the acknowledgement of Stalin's freedom of action regarding the terror, the theory of the "strong dictator." This is of the utmost importance.

In the framework of the "revisionists", the question of Stalin's personal motivations for initiating the "mass operations" of 1937-1938 is of secondary significance. Inasmuch as Stalin acted under pressure from the secretaries, the issue of primary importance is the motivations of the secretaries themselves. As Getty contends, they were afraid to lose elections. Of course, they had to make some sort of argument to Stalin, but this aspect of the matter is poorly articulated by Getty. Theoretically, we can suppose that the secretaries frightened Stalin with tales of plotting by numerous "enemies" and hinted that his "liberalism" was inappropriate. Zhukov argues that Stalin may have feared these political accusations of "liberalism." He was, after all, a weak dictator and therefore might even lose power.

In general, when it comes to the matter of substantive explanations, the "revisionist" position does not hold water. Getty's knee-jerk response is to dismiss out of hand all renditions supporting the traditional framework that Stalin possessed freedom of action. Getty attacks the most popular "traditionalist" explanations for Stalin's motivations: the destruction of a potential "fifth column." Getty emphatically repudiates this possibility. First, he contends, there was no growing threat of war at all in 1937. Second, he insists that in the documents related to the terror, this motivation is not discernable. It is not difficult to disprove both of these arguments with numerous facts.

42 Getty writes, "There were no threatening international events for months before or after the July 1937 launching of the mass operations." This is of course a misconception. It is not difficult for us to establish the synchronization of the terror within the USSR with growing international tensions. I will note only a few of most well-known events:

Cahiers du monde russe, $56 / 4$ | 2015 
the "appeasement" of the Nazis by the Western powers and the remilitarization of the Rhineland in March 1936; the beginning of the war in Spain on 18 July 1936; the passing of the Politburo resolution of 29 September 1936 on direct intervention in the events in Spain; the conclusion of the treaty between Italy and Germany on 25 October 1936; and the signing of the "Anti-Comintern Pact" between Germany and Japan on 25 November 1936. The longstanding threat in the Far East intensified after Japan's attack on China on 7 July 1937. In the USSR, these events formed the basis for a new phase of the elimination of former oppositionists, the result of which was the first major Moscow show trial in August 1936. On 29 September 1936, the same day that the Politburo passed its resolution to intervene in Spain, Ezhov was named the new head of the People's Commissariat of Internal Affairs. Repression received a renewed impetus. Stalin was extraordinarily active in following the situation in Spain as it escalated in 1937-1938. He issued a great many orders to the Soviet representatives in that country. He concluded that the headquarters of the Republican forces contained many spies and hidden enemies, and ordered their unmasking and elimination. ${ }^{31}$ Explaining the key to the "conspiracy" in the leadership of the Red Army to the members of the War Council of the USSR People's Commissar of Defense on 2 June 1937, Stalin declared, "They wanted to make a second Spain in the USSR." ${ }^{32}$ The expansion of the army and of war industries began to accelerate in $1936 .{ }^{33}$ The list of related facts might continue. ${ }^{34} \mathrm{All}$ of this bears witness to the fact that Stalin considered the world situation threatening. The very idea of a "fifth column" first appeared during the Spanish Civil, which he considered a possible scenario for the USSR.

It is especially necessary to underscore that the influence of external forces on domestic policy, and on the policy of the terror above all else, was one of the cornerstones of the Soviet system at each stage of its existence. The Bolsheviks came to power as a consequence of the First World War and always prepared for a new war. The threat of war and the threat of losing power were for the Bolsheviks interconnected challenges requiring energetic responses. James Harris reminds us of this again in his chapter in the volume in question.

There is more than a little evidence that the idea of the danger of a "fifth column" was firmly lodged in Stalin's mind between 1936 and 1938. Asserting that there is no documentary proof for this, Getty ignores "inconvenient" sources and calls attention to "convenient" documents. He ignores Stalin's speech to the Central Committee plenum of February-March 1937, in which the leader often spoke precisely of the threat of war. Getty ignores other related documents on Stalin. ${ }^{35}$ Getty's main argument is about the absence of direct reference to the external threat in order No.00447. Furthermore, Getty does not mention the so-called "national operations" against Soviet citizens of German, Polish, and other nationalities. ${ }^{36}$ In them, the intent to preventatively destroy supposed enemy states' agents comes through loud and clear. The chapter also withholds evidence when citing some documents. From Nikolai Bukharin's letter to Stalin from prison, Getty cites only one part of an important phrase: "Nikolai Bukharin wrote in his last letter to Stalin that a general purge was in part connected with "transition to democracy"' (p.230). In reality, Bukharin wrote that the purge was carried out "a) in conjunction with the prewar phase, b) in conjunction with the transition to democracy." 37

In recent years, many archival documents have come to light which reveal how Stalin's fears of collaboration between internal and external enemies were understood by the 
direct executors of the terror, the NKVD operatives. ${ }^{38}$ These documents have also been ignored by the "revisionists."

\section{The Theory of Popular Initiative}

trends in historiography have given special attention to social processes during the period of the Terror. How did people live during the time? What did they think? Did they take part in the terror or did they try to oppose state violence? Thanks to the opening of the archives, historians can, with a greater degree of certainty than before, make judgments about such questions. The contributors to the book in question have not avoided them. The chapter by Wendy Goldman is dedicated to the factory press, in which the theme of "enemies" took on a leading role in the years of the terror. The piece by William Chase is based on materials from party meetings in the apparat of the Comintern, which was also subjected to intensive purges. Both chapters are further evidence that the mass ideological campaigns were important components of the terror. Their goal was the mobilization of society behind Soviet leaders in the face of growing threats from enemies. of "brainwashing" under the conditions of the terror. The problem is in the conclusions. Both authors are inclined to see popular initiative as the driving force of the terror, rather than as a central strategy to mobilize popular support for the terror campaign. Goldman puts her argument this way, writing "Although central party leaders launched a series of campaigns that initiated terror on the local level, the hollowing out of leadership at every level-shop, party, district, town, and regional committees-created a chaotic war of each against all." Chase transplants into Stalinist soil the results of general research into phenomena such as "scapegoating." "There is no question that the scale of repression in the USSR in the 1930s was exceptional, but the behaviours that contributed to it were sadly universal human behaviours," writes Chase (280). Noting the contributions of Goldman and Chase, the volume's editor concludes, "Without mass participation and support, it is unlikely that the repression would have spread so rapidly, or claimed so many victims" (239). In this view, citizens sent more and more denunciations of "enemies," and the NKVD, in response, carried out more and more arrests.

The main weakness in the theory of popular initiative, as in other "revisionist" approaches to the study of the Great Terror, is in the weakness of the documentary evidence, and in the disregard for a whole assemblage of historiography and sources. Large-scale conclusions are made on the basis of a small group of very specific documents. Chase studies only two events, one of which is related to the campaign of 1934-35, following the Kirov murder. And the second at least as easily contradicts Chase's general conclusions. A Comintern employee arrested in 1937, about whose fate Chase writes, was discussed at a meeting only after the arrest by the NKVD. At the very least, no "popular action" initiated the destruction of this person.

Neither Goldman nor Chase delved into the large literature on the organization of the terror as a whole or on the lower level. It is as if their case studies hang in the air, outside the contexts of events and of historiography. Putting forth their theory of society as the driving force of the terror, they do not explain how the other theories fail.

Cahiers du monde russe, $56 / 4$ | 2015 

supporting role in the escalation of the terror. The chekisty possessed an inventory of "enemies" and "suspicious figures" in their own files, which had been accumulated over several years. This inventory served as the basic intelligence for the mass operations. ${ }^{39}$ To some degree, in the spread of the terror other methods for exposing "enemies" were applied. Apart from the lists of names in the NKVD's own catalogs, the most common basis for opening new cases was the "evidence" pried from arrestees with the aid of torture. Any sort of "terrorist" or "espionage" organization could be quickly constructed from among the acquaintances, friends, relations, and neighbors of the arrested "enemy." In addition, NKVD operatives requested documentation from various organs of government (above all, the village soviets) on social origins, nationality, and other characteristics. On the basis of such documentation, arrests were made. Roundups were carried out in villages or on construction sites where former "kulaks" lived and worked, as well as in marketplaces and the like. People accidentally caught up during these roundups were tortured in questioning and forced to acknowledge participation in "terrorist organizations." ${ }^{40}$

51 Such mass methods of exposing "enemies" had evident advantages for the chekists. They allowed them to fulfill their growing quotas for arrests quickly. Arriving more or less spontaneously, denunciations lacked such advantages. As a result, investigations consisted primarily of confessions received during questioning, as the research shows. In the archive of the Tomsk oblast directorate of the FSB, denunciations were found in fewer than 0.5 percent of the studied cases. ${ }^{41}$ Researchers have established that the NKVD ignored signals from below, even incriminating materials arriving from party organs. NKVD operatives, well-versed in fabricating the "confessions" of those arrested, stopped working with their agents. ${ }^{42}$ As researchers have judged, some of the preserved denunciations were written by "staff witnesses" or agents at the orders of NKVD personnel, which is to say that they were not actually denunciations in the literal sense of the word ${ }^{43}$ Having started the assembly line of torture, the chekisty were in possession of a surplus of "candidates" for new arrests and did not need to be helped out by denouncers. At the end of 1937, Ezhov sent an order to the krai and oblast directorates of the NKVD to report on conspiracies unmasked with the aid of workers and kolkhozniks. The results were underwhelming. A typical cypher arrived on 12 December 1937 from the head of the Omsk NKVD directorate: "There were no instances of unmasking of espionage-sabotage Trotskyite-Bukharinist or other organizations at the initiative of kolkhozniks or workers." ${ }^{44}$

52 As Sheila Fitzpatrick long ago observed, in 1937-1938 the denunciations generally comprised merely one of the sources of "compromising information." In contrast to Nazi Germany, they were not the typical starting point for investigations by the Soviet NKVD. ${ }^{45}$ Stalinist terror and mass denunciations were connected phenomena, albeit as a rule, autonomous ones. Activated insofar as the terror grew, denunciations doubtlessly served as the basis for some number of arrests. Yet the true reasons for the escalation of "mass operations," their goals, and their directions were not at all determined by "popular action." They depended on the orders of the top leadership of the country and the actions of the punitive organs, who were programmed to fabricate cases about mass-based and far-flung "counterrevolutionary organizations."

53

Not all ideas expressed in previous decades survive the test of time. In the case of Soviet history, this banal truth is doubly correct. The opening of archives that had been 
completely inaccessible before the beginning of the 1990s fundamentally altered our conceptions of many events of the Stalin era. Approximately thirty years have passed since the basic postulates of "revisionism" formed about the essence and mechanisms of Stalinist terror, including more than twenty years of intensive study of the archives. This length of time is sufficient to evaluate the achievements and potential of this tendency.

First, it can be noted that contemporary "revisionism" in the study of the Great Terror has not retreated from its original and fundamental positions. It continues to postulate the weakness of the Stalinist dictatorship and of Stalin himself as a dictator, as if he were subjected to significant influence from the nomenklatura. It overstates the significance of spontaneity and pressure from below in the terror of the 1930s. In contrast to these arguments, the "traditionalists" find even more reason to consider Stalin a "strong dictator." "Traditionalists" insist on the centralized character of the "mass operations" of 1937-1938, and the guiding hand of Stalin in their initiation and implementation. Of course this assertion does not mean that the "traditionalists" ignore all of the complexities of these tragic events or consider them a colossal machine, acting according to a carefully designed plans without interruptions and speed-ups: that is, to use the jargon of Stalin's time, without "peregiby." For the "traditional" approach, only one fact is of primary importance: the power of Stalin was sufficiently strong to initiate and control the "mass operations," and at a particular moment to curtail them in a centralized manner. It is this essential point of fact that the "revisionists" challenge.

Concentrating on the motivations of the terror of 1937-1938, contemporary "revisionists" give it a universal meaning that it did not, in reality, possess. From this important yet unique episode in Soviet history, the "revisionists" strive to draw conclusions about the system as a whole. In practice, however, they do not move beyond the boundaries of 1937. They are not interested in the mechanism for cutting off the "mass operations" in 1938, to say nothing about other events between the 1930s and the 1950s. Such a narrow perspective distorts the general outlook of their analysis of the Stalinist system. Clearly, other phenomena of Soviet history require as much detailed research as the "mass operations" of 1937-1938 have received, and should not be a priori considered with reference to these operations. Putting it another way, in some events and phenomena we see evidence of an "expansive" dictatorship, but in others - a "lesser" dictatorship. Yet in 1937 and 1938, the dictatorship was there in excess.

One of the prejudices carefully cultivated by contemporary "revisionists" is that they, in contrast to the "traditionalists," in some way are social historians and consider processes from the bottom up, while the "traditionalists" all reduce everything to the history of Kremlin offices. This argument a priori provides "revisionists" with an advantage. Clearly and indisputably, the history of the country in the conditions of the dictatorship was much more complex than the story of the dictator himself.

At the same time, in reality the pretensions of the contemporary "revisionists" to possession of a special perspective on Soviet history-"top-down vs. bottom-up," as the editor of the volume writes in the introduction-is a clear misunderstanding and distortion of the perspective of their opponents. First, the contemporary "revisionists" have not done so much for the understanding of the complicated interconnections between social and political processes. Second, the proponents of the "traditional" 
point of view have never considered Stalin alone the cause of the terror. Instead, they actively study the social history of the terror, and the interactions among the various structures and levels of the Stalinist system. To be convinced of that, it is necessary only to read the works on the terror that have been published in the last ten to fifteen years.

The relationship of the contemporary "revisionists" to those facts is entirely selective. Even after the opening of the archives, they construct their presuppositions on the basis of a few carefully selected archival documents. It is this disregard for the whole body of sources and literature that allows the "revisionists" to maintain the purity of their framework. The volume at hand clearly demonstrates that tendency. Chapters by contemporary "revisionists," tend to cite works primarily within their own circle, or only select archival sources. If it is advantageous, the "revisionists" are prepared to cite even the doubtful work of marginal historians or of radical publicists, as in the example of Getty, discussed above, in relation to the books of Zhukov and Eliseev. The "revisionists" note works of opponents only formalistically. Debates on substance are supplanted by abstract declarations. Contemporary "revisionism" declines to respond to direct and specific questions that have already been asked by its opponents for many years. It substitutes phraseology for factual analysis. In general, contemporary "revisionism" more and more transforms itself into a sort of "historiographic sect," only weakly in contact with other researchers.

We cannot discount that the logic of development of contemporary "revisionism" reflects a general problem confronting current Soviet historiography. The wholesale opening of the Soviet archives and the precipitous increase of the quantity of research put historians in a very difficult position. We cannot keep up with all the publications appearing, and therefore miss many new developments. This tendency increases the danger of the formation of tight professional groups specializing in narrow themes, the members of which are in contact with one another but are not interested in what happens beyond the bounds of their group. The great streams of empirical information allow many authors to publish the same work, for decades at a time, and to ignore completely the critiques of their opponents. It seems that such shortcomings are becoming more widespread than we would prefer.

\section{NOTES}

1. I am grateful to Anna Joukovskaia, Marc Elie, David Shearer, Seth Bernstein, Angelina Lucento, and Aaron Hale-Dorrell for their valuable comments and skillful translation. This article was prepared within the framework of a subsidy granted to the HSE by the Government of the Russian Federation for the implementation of the Global Competitiveness Program.

2. James Harris, ed., The Anatomy of Terror: Political Violence Under Stalin (Oxford: Oxford University Press, 2013)

3. One of the more significant is the collaborative project that was carried out by German, Russian, and Ukrainian historians, the results of which have been published in a series of books: M. Iunge, R. Binner, Kak terror stal "bol'shim": Sekretnyi prikaz No. 00447 i tekhnologiia ego 
ispolneniia [How the Terror became "Great": Secret Order No. 00447 and the Technology of Its Implementation] (M.: AIRO-XX, 2003); M. Iunge, G. Bordiugov, and R. Binner, Vertikal' bol'shogo terrora: Istoriia operatsiia po prikazu NKVD No. 00447 [The Vertical of the Great Terror: The History of the Operation according to NKVD Order No. 00447] (M.: Novyi khronograf, 2008); B. Bonvech, et al., eds., Stalinizm v sovetskoi provintsii, 1937-1938 gg: Massovaia operatsiia na osnove prikaza No. 00447 [Stalinism in the Soviet Provinces, 1937-1938: The Mass Operation on the Basis of Order No. 00447] (M.: ROSSPEN, 2009); M. Iunge, B. Bonvech, and R. Binner, eds., Massovye repressii v Altaiskom krae, 1937-1938 gg.: Prikaz No. 00447 [Mass Repression in the Altai Region, 1937-1938: Order No. 00447], (M.: ROSSPEN, 2010); M. Iunge, S.A. Kokin, R. Binner, et al., eds., "Cherez trupy vraga na blago naroda": Kulatskaia operatsiia v Ukrainskoi SSR, 1937-1941 gg. ["Over the Enemy's Dead Body, for the Good of the People": The Kulak Operation in the Ukrainian SSR, 1937-1941], 2 vols. (M.: ROSSPEN, 2010); and others.

4. L.A. Liagushkina, "Sotsial'nyi portret repressirovannykh $\mathrm{v}$ khode Bol'shogo terrora (1937-1938 gg.): Analiz bazy dannykh po knigam pamiati Nizhegorodskoi oblasti" [A Social Portrait of Those Repressed during the Great Terror (1937-1938): An Analysis of Evidence from Memorial Books in the Nizhny Novgorod Oblast], Istoricheskaia informatika no. 1 (2012): 30-43; L.A. Liagushkina, “Sotsial'nyi portret repressirovannykh v khode Bol'shogo terrora v Bashkirskoi ASSR: Analiz bazy dannykh po knigam pamiati po regional'nym 'knigam pamiati' [A Social Portrait of Those Repressed during the Great Terror in the Bashkir Republic: An Analysis of Evidence from Regional "Memorial Books"]" in Istoriia stalinizma: Zhizn' v terrore. Sotsial'nye aspekty repressii [The History of Stalinism: Life during Terror. The Social Aspects of Repression] (M.: ROSSPEN, 2013), 305-315.

5. See, for example, observations on the significant underestimations of the number of individuals shot in 1933 found in ministerial records: A.G.Tepliakov, "Dinamika gosudarstvennogo terrora v SSSR v 1933 godu: Novye dannye [The Dynamics of State Terror in the USSR in 1933: New Data]," Vestnik Novosibirskogo gosudarstvennogo universiteta (Series: Istoriia, filologiia), vol. 12, no. 1, Istoriia (2013): 50-54.

6. V.P. Danilov, et al., eds., Tragediia sovetskoi derevni: Kolletivizatsiia i raskulachivanie, 1927-1939 [The Tragedy of the Soviet Countryside: Collectivization and Dekulakization, 1927-1939], vol. 5, book 2 (M.: ROSSPEN, 2006), 567-568. (From the materials of A. Roginskii and N. Okhotin).

7. I have borrowed this understanding from David Shearer's chapter in the volume under review. He writes that these historians follow "traditional arguments about the peculiarities of time, place and sequence" (108).

8. David R. Shearer, Policing Stalin's Socialism: Repression and Social Order in the Soviet Union, 1924-1953 (New Haven, CT - London: Yale University Press (Yale-Hoover Series on Stalin, Stalinism, and the Cold War), 2009); Paul Hagenloh, Stalin's Police: Public Order and Mass Repression in the USSR, 1926-1941 (Washington, DC - Baltimore: The Woodrow Wilson Center Press and the Johns Hopkins University Press, 2009).

9. He characterizes his own new book as one that "continues the tradition of the most conservative revisionism." Gábor T. Rittersporn, Anguish, Anger and Folkways in Soviet Russia (Pittsburgh: University of Pittsburgh Press, 2014), 3.

10. The space of an article makes it impossible to list even a small portion of this literature. I will name several general works and document collections in addition to those that have been listed previously: Lynne Viola, Peasant Rebels under Stalin: Collectivization and the Culture of Peasant Resistance (Oxford - New York: Oxford University Press, 1996); A.E.Gur'ianov, ed., Repressii protiv poliakov i pol'skikh grazhdan [The Repression of Poles and Polish Citizens] (M.: Zven'ia, 1997); Marc Jansen and Nikita Petrov, Stalin's Loyal Executioner: People's Commissar Nikolai Ezhov, 1895-1940 (Stanford, CA: Hoover Institution Press, 2002); B. McLoughlin and K. McDermott, eds., Stalin's Terror: High Politics and Mass Repression in the Soviet 
Union (Basingstoke, UK: Palgrave MacMillan, 2003); N. Vert and S.V. Mironenko, eds., Istoriia stalinskogo Gulaga: Konets 1920-x - pervaia polovina 1950-kh godov [The History of Stalin's Gulag: From the End of the 1920s through the First Half of the 1950s], vol. 1: Massovye repressii v SSSR [Mass Repressions in the USSR] (M.: ROSSPEN, 2004); A. Vatlin, Terror raionnogo masshtaba: «Massovye operatsii» NKVD v Kuntsevskom raione Moskovskoi oblasti, 1937-1938 gg [Terror on a District Scale: The "Mass Operations" of the NKVD in Moscow's Kuntsevo District] (M.: ROSSPEN, 2004); Lynne Viola, The Unknown Gulag: The Lost World of Stalin's Special Settlements (New York: Oxford University Press, 2007); A.G. Tepliakov, Mashina terrora: OGPU-NKVD Sibiri v 1929-1941 gg [The Machine of Terror: The OGPU-NKVD of Siberia, 1929-1941] (M.: Novyi Khronograf, 2008) O.L. Leibovich, et al., eds., "Vkliuchen v operatsiiu": Massovyi terror v Prikam 'e v 1937-38 gg ["Included in the Operation": Mass Terror in the Kama Region in 1937-38] (M.: ROSSPEN, 2009); V.N. Khaustov and L. Samuel'son, Stalin, NKVD i repressii, 1936-1938 [Stalin, the NKVD, and Repression, 1936-1938] (M.: ROSSPEN, 2009); N. Vert, Terror i besporiadok: Stalinizm kak sistema [Terror and Disorder: Stalinism as a System] (M.: ROSSPEN, 2010); S. Papkov, Obyknovennyi terror: Politika stalinizma v Sibiri [Ordinary Terror: The Politics of Stalinism in Siberia] (M.: ROSSPEN, 2012); David R. Shearer and Vladimir Khaustov, Stalin and the Lubianka: A Documentary History of the Political Police and Security Organs in the Soviet Union, 1922-1953 (New Haven, CT - London: Yale University Press, 2015). An enormous quantity of documents and research on the terror of the 1930s is being published in Ukraine, where the archives of the Soviet punitive system have now been completely opened. Electronic versions of many publications and a special journal can be found on the site of the editorial board of the series of books "Rehabilitated by History": http://www.reabit.org.ua. The majority of the documents have been published in the language of the originals, that is to say, in Russian.

11. R. Podkur and V. Chentsov, Dokumenty organov gosudarstvennoi bezopasnosti USSR, 19201930-kh godov: Isotchnikovedcheskii analiz [Documents from the State Security Organs of the Ukrainian SSR, 1920s-1930s: A Source Analysis] (Ternopol': Zbruch, 2010), 142-151; V.N. Khaustov, "Razvitie sovetskikh organov gosudarstvennoi bezopastnosti, 1917-1953" [The Evolution of the Soviet State Security Organs, 1917-1953], Cahiers du monde russe 42, 2-4 (2001): 370; Bonvech, et al., eds., Stalinizm v sovetskoi provintsii, 393-394.

12. V.E. sKorneev and O.N. Kopylova, “Arkhivy na sluzhbe totalitarnogo gosudarstva (1918 nachalo 1940-kh gg.) [Archives in Service to the Totalitarian State, 1918 - early 1940s], Otechestvennye arkhivy [Fatherland Archives], no. 3 (1992): 13-24.

13. Directives that regulated the initiation of the "mass operations" of 1937-38 have been published several times in different outlets. They have been collected in the following books: N. Vert and S.V. Mironenko, eds., Istoriia stalinskogo Gulaga, vol. 1. For the publication of order No. 00447 in English, see: J. Arch Getty and Oleg V. Naumov, eds., The Road to Terror: Stalin and the Self-Destruction of the Bolsheviks, 1932-1939 (New Haven, CT: Yale University Press, 1999), 473-478.

14. R.W. Thurston, Life and Terror in Stalin's Russia, 1934-1941 (London - New Haven, CT: Yale University Press, 1996).

15. RGASPI (Rossiiskii gosudarstvennyi arkhiv sotsial'no-politicheskoi istorii ), f. 17, op. 3, d. 987, 1. 58 .

16. The numbers were determined on the basis of decisions of the Politburo.

17. Getty and Naumov, eds., Road to Terror, 469.

18. Khaustov and Samuel'son, Stalin, NKVD i repressii, 262-263.

19. Michael Ellman, "Regional Influences on the Formulation and Implementation of NKVD Order 00447," Europe-Asia Studies 62, 6 (August 2010): 917.

20. Khaustov and Samuel'son, Stalin, NKVD i repressii, 333.

21. Michael Ellman provides an analysis of the relationship between the center and regional powers, which ensued from the channels of Stalin's instructions and at the same time 
strengthened Stalin's commitment to carrying out the politics of the Terror. Ellman, "Regional Influences on the Formulation."

22. Iu.N. Zhukov, Nastol'naia kniga stalinista (M.: Eksmo, 2010).

23. "Neizvestnyi 37-i" [The unknown year 1937], Literaturnaia gazeta, no. 28 (July 11, 2012): 9; <http://old.lgz.ru/article/19401/>.

24. Iu.N. Zhukov, Inoi Stalin: Politicheskie reformy v SSSR v 1933-1937 gg. [The Other Stalin: Political Reforms in the USSR, 1933-1937] (M.: Vagrius, 2003).

25. I.V. Pavlova, “1937: Vybory kak mistifikatsiia, terror kak real'nost" [1937: Elections as Hoax, Terror as the Reality], Voprosy istorii [Problems of history], no. 10 (2003): 19-37; G.I. Cherniavskii, "Novye falsifikatsii "bol'shogo terrora" [New Falsifications of the "Great Terror"], Voprosy istorii, no. 12 (2009): 155-164.

26. J. Arch Getty, review of Stalin's Police: Public Order and Mass Repression in the USSR, 19261941 by Paul Hagenloh, in Slavic Review 69, no. 3 (Fall 2010): 772.

27. J. Arch Getty, Practicing Stalinism: Bolsheviks, Boyars, and the Persistence of Tradition (New Haven, CT: Yale University Press, 2013), 208 and 233.

28. Notably, reliance on the works of Zhukov is not the first instance when Getty uncritically used doubtful works by Russian writers. In the volume Stalinist Terror: New Perspectives (New York: Cambridge University Press, 1993), which Getty edited, "facts" invented by a Russian historian about a struggle in the Politburo in 1937-1938 were published. In the introduction to the volume, Getty held that these "facts" confirmed "revisionist arguments... about Stalin's ambiguous power at the end of the terror." Yet it quickly became clear that the "sensation" of the Russian historian cited by Getty was a falsification. For an explanation, see: O.V. Khlevniuk, "Upravlenie gosudarstvennym terrorom [Administering State Terror]," Svobodnaia mysl', nos. 7-8 (1994), 125-126. Getty never responded to the critique.

29. R.W. Davies, review of The Anatomy of Terror: Political Violence under Stalin, edited by James R. Harris, in Europe-Asia Studies 67, 5 (2015): 832.

30. Hiroaki Kuromiya, “Accounting for the Great Terror," Jahrbücher für Geschichte Osteuropas 53, 1 (2005): 88-90.

31. Oleg Khlevniuk, “The Reasons for the 'Great Terror': The Foreign-Political Aspect," in Silvio Pons and Andrea Romano, eds., Russian in the Age of Wars, 1914-1945 (Milan: Feltrinelli, 2000). On the enormous attention the Soviet leadership devoted to the war in Spain, see the Politburo documents in: SSSR i grazhdanskaia voina v Ispanii, 1936-1939 gg. [The USSR and the Civil War in Spain, 1936-1939] (M.: Vestnik Arkhiva Prezidenta Rossiiskoi Federatsii, 2013).

32. N.S. Tarasov, et al., eds., Voennyi sovet pri narodnom kommissare oborony SSSR, 1-4 iiunia 1937 g.: Dokumenty i materialy [The War Council of the USSR People's Commissar of Defense, June 1-4, 1937: Documents and Materials] (M.: ROSSPEN, 2008), 133.

33. R.W. Davies and Mark Harrison, "The Soviet Military-Economic Effort during the Second Five-Year Plan, 1933-1937," Europe-Asia Studies 49, - 3 (1997): 373 and 406. For more on the links between the rearmament and the mass repressions under the threat of war, see: Mark Harrison, ed., Guns and Rubles: The Defense Industry in the Stalinist State (London - New Haven, CT: Yale University Press, 2008), 1-30.

34. Kuromiya, "Accounting for the Great Terror," 86-101; and Kuromiya, "Stalin's Great Terror and International Espionage," The Journal of Slavic Military Studies 24, 2 (2011): 238-252.

35. On the documents reflecting Stalin's ideas on the theme of activating internal enemies during wartime conditions, see: Oleg V. Khlevniuk, Master of the House: Stalin and His Inner Circle (London - New Haven, CT: Yale University Press, 2008), 174-176.

36. As Hiroaki Kuromiya notes, Getty "disaggregates the Great Terror, focusing on the kulak operation and separating it from the "national' operations and others." Kuromiya, "Accounting for the Great Terror," 87. 
37. "Prosti menia, Koba...: Neizvestnoe pis'mo N. Bukharina" [Forgive me, Koba...: The unknown letter of N.I. Bukharin], Istochnik: Dokumenty russkoi istorii [The Source: Documents in Russian History], no. 0 (1993): 23.

38. Ellman, "Regional Influences on the Formation," 918.

39. Numerous NKVD documents about the use of these intelligence inventories as the basis for carrying out the mass operations are published in the book: Iunge, Kokin, Binner, et al., eds., "Cherez trupy vraga na blago naroda", 29, 32, 36-41, 82-85, 98, 139-140, 141.

40. A.G. Tepliakov, “Organy NKVD Zapadnoi Sibiri v 'kulatskoi operatsii', 1937-1938 gg." [NKVD Organs of Western Siberia in the "kulak operation," 1937-1938], in Bonvech, et al., eds., Stalinizm v sovetskoi provintsii, 1937-1938 gg., 552-553; and Vert and Mironenko, eds, Istoriia stalinskogo Gulaga, 1: 344 .

41. V.N. Uimanov, Repressii: Kak eto bylo...: Zapadnaia Sibir' v kontse $20-\mathrm{kh}$ - nachale $50-\mathrm{x}$ godov [Repressions: How it was... Western Siberia from the end of the '20s to the beginning of the '50s] (Tomsk: Izdatel'stvo Tomskogo universiteta, 1995), 89. Analogous observations are contained in the work of other researchers working on investigative cases. See: S.M. Popova, "Sistema donositel'stva v 30-e gody (K problemu sozdaniia bazy dannykh na materialakh Urala)" [The system of denunciations in the " 30 s (On the issue of creating a dataset based on documents from the Urals)], Kilo, 1 (1991), 71-72. A similar analysis of the content of investigative cases and materials, on the basis of which arrests were carried out, is carried out in the contributions to the volume: Bonvech, et al., eds., Stalinism v sovetskii provintsii, 1937-1938 gg.

42. Leibovich, et al., eds. "Vkliuchen v operatsiiu," 77; A.F. Stepanov, "Bolshoi terror v Tatarskoi ASSR: Massovaia 'kulatskaia' operatsiia po prikazy NKVD SSSR No. 00447" [The Great Terror in the Tatar ASSR: Mass "kulak" operation according to USSR NKVD order No. 00447], in Istoriia stalinizma: Repressirovannaia provintsiia [The history of Stalinism: The repression of the provinces], ed. E.V. Kodin (M.: ROSSPEN, 2011), 186-187.

43. Tepliakov, "Organy NKVD Zapadnoi Sibiri," 555-556. In the investigative files, V.N. Razgon discovered several "statements" of seeming former red partisans written on the same day and in the same hand: "Repressii protiv byvshikh 'kulakov' v Altaiskom krae v 1937-1938 gg." [Repressions against the former "kulaks" in Altai krai, 1937-1938], in Bonvech, et al., eds., Stalinizm v sovetskoi provintsii, 101; David R. Shearer, Policing Stalin's Socialism, 354-356; Shearer and Khaustov, Stalin and the Lubianka, 211.

44. Khaustov and Samuel'son, Stalin, NKVD, i repressii, 278.

45. Sheila Fitzpatrick, "Signals from Below: Soviet Letters of Denunciation of the 1930s," Journal of Modern History 68, 4 (December 1996): 834.

\section{AUTEURS}

\section{OLEG KHLEVNIUK}

National Research University Higher School of Economics (Russian Federation), International Center for the History and Sociology of World War II and its Consequences 